\title{
Evolving of Selected Integrated Reporting Capitals among Listed Bahraini Banks
}

\author{
Husain Alqallaf \\ Treasury Department, \\ Arab Shipbuilding and Repair Yard Bahrain \\ Kingdom of Bahrain

\section{Bahaaeddin Alareeni} \\ Accounting and Economics Department, \\ Ahlia University, \\ Manama, \\ Kingdom of Bahrain \\ and \\ Accounting Department, \\ University College of Applied Sciences, \\ Gaza, Palestine \\ Email: bahaaedu@hotmail.com \\ *Corresponding author
}

13 Manama,

Received October, 2017; Accepted January, 2018

\begin{abstract}
The purpose of this study is to synthesize the implementation level of Integrated Reporting (IR) in Bahraini banks based on their adoption of a comprehensive disclosure checklist. The data cover the period of 2014-2015 for 12 banks listed on Bahrain Stock Exchange. Using 38 disclosure items grouped into four categories (intellectual capital, social and relational capital, intellectual capital, and human capital), banks' annual reports were content analyzed to evaluate the level of IR disclosure. The findings indicate that the overall implementation level was moderate, standing at $65.54 \%$ and $67.79 \%$ in 2014 and 2015 , respectively, showing a slight increasing trend. The findings also reveal that BBK took the lead with a disclosure percentage of $70.27 \%$ and $75.68 \%$ in both years. In terms of categories, the highest level of implementation was recorded for human capital, with a level of $81.3 \%$ and $80.2 \%$ in 2014 and 2015 respectively, while the lowest level of implementation was noted for social and relational capital.
\end{abstract}

Keywords: Firm- Integrated Reporting; Voluntary Disclosure; Sustainability; Legitimacy Theory.

Type: Research paper

This work is licensed under a Creative Commons Attribution 4.0 International License.

\section{DOI: 10.51325/ijbeg.v1i1.10}

\section{Introduction}

In the Worldwide, including Bahrain; business investor's capital market and the broader economy depend on the provision of high quality, value-relevant information for 
the efficient and effective allocation of resources, to encourage a vibrant climate for investment (IIRC 2013). The aim of an Integrated Reporting (IR) is to drive and provide a concise, holistic account of company value and performance by reporting a comprehensive range of financial, human, intellectual, environmental and social factors that impact company's short, medium and long-term capacity for value creation. As such, it incorporates but goes beyond the types of information currently reported in companies' financial statements (Al-Sartawi, 2013; lareeni and Lulu, 2014; Alareeni, 2017; Al-Sartawi, 2017). Companies have increasingly utilized mechanisms, beyond financial statements to satisfy increased stakeholder demand for information, the top instrument for which has been stand-alone sustainability reports (Simnett 2009). While the practice of issuing standalone sustainability reports is now a mainstream business practice, one of the major criticisms of this practice is the sheer volume of information produced often without identification of strategic or financial implications. This has rendered a little use to information users, especially providers. According to the International Integrated Reporting Council (IIRC 2013) which was founded in 2011, IR can be defined as an integrated report which is a concise communication on how an organization's strategy, governance, performance and prospects, in the context of its external environment lead to the creation of value over the short, medium and long term. IR is needed to achieve main goals first to legitimize the firm and make it closer to its surrounding environment witch well lead to an increase the price of the shares and gaining the trust of the society, second IR gives the shake holder a complete understanding of the firm performance and strategy.

The concept of integrated reporting has been undertaken by two separate bodies, the King Report on Governance for South Africa (King III) (and the International Integrated Reporting Council in the U.K. Preparing an integrated report became mandatory starting 1 March 2010 for organizations listed on the Johannesburg Stock Exchange. Elsewhere in the world, several organizations are trialing preparations of an integrated report with the concept, process, and reporting still evolving, and with no unified description of this concept

King III describes integrated reporting as "a holistic and integrated representation of the company's performance in terms of both its finance and its sustainability" (IRCSA, 2011, p. 3). According to the King III report, the overall objective of integrated reporting is to help stakeholders assess whether an organization can create and sustain its value over the short, medium, and long term. King III states that integrated reporting is an approach by which organizations demonstrate their responsibility towards the global economy and the three major stakeholders: shareholders, society, and the environment (IRCSA 2011).

Going across an area that has not been explored in our modern day financial reporting, it is very important to examine the level of IR in Bahraini banking sector. This study explores the unexplored area with a review throwing a series of analysis to reveal a conclusion of what is being disclosed in the financial reports. A measurement of the IR implementation and the level of disclosure need to be examined to identify the level of 
financial reporting in Bahrain and where is it heading. After getting an idea on Bahraini banking sector, financial disclosure levels to a futuristic research. This can examine the value creation aspects in the implementation of IR.

Based on the above discussion, this study seeks to explore application level of Integrated Reporting (IR) in financial reports among Bahraini banking sector. It tests whether there is a change/progress in the extent of applying Integrated Reporting (IR) in two years 2014 and 2015. In addition, it measures the differences in the quantity of the IR among listed banks on the Bahrain Bourse.

Therefore, the study has very encouraging business potentials, as these days banks in Bahrain needs to objectify their financial reports to the level of comprehensive disclosures. This study further provides decision makers with the required information on any significant decision making and measuring the value of the firm from a holistic point of view. The importance of the study is demonstrated by showing the level of disclosures and displays on where the financial reporting is heading in Bahraini banking sector. Further, it provides evidence to the banks' management and board of directors if they have to increase the level of the IR or not.

Section 1 being introduction, further part of this study is divided into five sections. Section 2 discusses literature review. Section 3 presents the design and research methodology. Section 4 shows the descriptive statistics and analysis results. Section 6 presents the study's conclusion, recommendations and the scope for further research.

\section{Literature review and integrated reporting}

In order to evaluate the level of involvement among Bahraini banks in integrated reporting, it is important to explore, examine and understand two areas of integrated reporting. That is, legitimacy theory and how firms disclose their annual report. Hence; this chapter review and examine these concepts along with explanation on why we need IR. Apart from these, all-inclusive studies related to the purpose needs to be examined which are as follows:

Lozano, Valencia (2016) aimed to understand the state of affairs in the level of attention of the principles of IR in the industrial companies which have adopted this initiative in their communications concerning the achievement of a sustainable environment. The results showed that, despite the efforts of the analyzed companies to address the guiding principles, they still have a long way to go, especially in relation to the principle of "conciseness". It has also been proven that the companies analyzed were not influenced by the environment relating to the level of attention given to the incorporation of this type of reporting. Setia et al. (2015) aimed to utilize authenticity hypothesis to define two option anticipates how JSE-recorded partnerships may reveal data identifying with various capitals, as portrayed by the International Integrated Reporting Committee, in light of the King III Code. Yearly/coordinated reports of the main 25 JSE recorded organizations for the years 2009/2010 and 2011/2012 are contentbroke down for the nearness of data on capitals. The adjustment in the degree of divulgence of capitals is examined utilizing t-tests to test the recommendations. The 
results demonstrated that the presentation of incorporated revealing in South Africa has brought about an expansion in the degree of exposure of human, social and social, normal and scholarly capital data of the recorded organizations. The augmentation in the divulgence of social and social capital is factually essentially more prominent than the addition in the revelation of different capitals. The discoveries show that JSE-recorded organizations are receiving a legitimating system in view of typical administration when planning incorporated reports. Halbritter and Dorfleitner (2015) aimed to investigate the link between the corporate social and financial performance based on environmental, social and corporate governance (ESG) ratings and to reviewing the existing empirical evidence pertaining to this relationship. The sample used includes ESG data of ASSET4, Bloomberg and KLD for the U.S. market from 1991 to 2012. The econometrical framework applies an ESG portfolio approach using the Carhart (1997) four-factor model as well as cross-sectional Fama and MacBeth (1973) regressions. This research indicated a relationship between ESG ratings and returns. As against this, the ESG portfolios do not state a significant return difference between companies with high and low ESG ratings. Although the Fama and MacBeth (1973) regressions reveal a significant influence of several ESG variables, investors are hardly able to exploit this relationship. The magnitude and direction of the impact are substantially dependent on the rating provider, the company sample and the particular sub period. The results suggest that investors should no longer expect abnormal returns by trading a difference portfolio of high and low rated firms with regard to ESG aspects. De Villiers et al. (2014) aimed to synthesize insights from accounting and accountability research into the rapidly emerging field of integrated reporting and proposed a comprehensive agenda for future research in this area. The study showed that the rapid development of integrated reporting policy, and early developments of practice, presented theoretical and empirical challenges because of the different ways in which integrated reporting is understood and enacted within institutions.

Alareeni and Lulu (2014) aimed to focus on the measurement of quality and quantity of the voluntary disclosures in a Palestine listed companies in 2014 (base year) through a checklist method. The study gave a comprehensive evaluation of the status of the voluntary disclosure. The results showed that the voluntary disclosure level was varied from one industry to another, and even between companies within an industry. The banking sector was the most committed sector to the voluntary disclosure by $70 \%$, and the less committed sector was the real estate sector by $36 \%$. Overall, the voluntary disclosure level for sectors as a whole was $54 \%$. This indicated that the companies do not significantly disclose the voluntary disclosure, and need to strengthen and requires attention. It showed that voluntary disclosure level does not significantly affect the stock price. García-Sánchez at al. (2013) examined the effect of national cultural systems on integrated reporting based on 1590 corporations from twenty nations from 2008 to 2010. Corporations were chosen from the Forbes Global 2000 list. Each of Hofstede's dimensions (including long-term focus) was involved as a dependent variable in the analysis and subject to an econometric model based on data dependence analysis. The findings showed that at a firm level, firm size, industry and profitability are positively 
correlated with the extent of complete (integrated) reporting. At a broader level, companies based in countries with a collectivist, feminist cultural system (with a focus on corporate ethics, sustainability and good governance) tend to publish integrated reports. The study relied on Hofstede's (2011) cultural dimensions: individualism versus collectivism, masculinity versus femininity, tolerance versus aversion to uncertainty and power versus distance. Dragu and Tiron-Tudor (2013) investigated correlations between the voluntary adoptions of integrated reporting and political, cultural and economic factors. This is a very small study which does not offer much element on the method and findings. It is based on the reports of 58 companies in the IIRC pilot project for 2010 to 2012. The study found that political and economic factors are definitely correlated with the voluntary adoption of integrated reporting. Social responsibility indices are surprisingly negatively correlated. Makiwane and Padia (2013) aimed to test the levels of corporate governance disclosures. The study did not reveal integrated reporting initiatives clearly but does provide a comprehensive review of the degree of nonfinancial information being involved in annual reports following the release of King-III. Fourteen disclosure categories are used to analyze trends in non-financial disclosures including ethical leadership and corporate citizenship; the activities of boards of directors and committees of the board; the governance of information technology; internal audit; and social, environmental and economic suitability. Aggregate of hundred and eleven indicators from King-III and the GRI (2011) are used to analyze the financial reports of ninety-two companies reviewed and examined changes in the amount of nonfinancial disclosures from 2009 (the base year) to 2010. The findings of this study reveal improvements in the level of IR by South African listed companies.

Jensen and Berg (2013) examined certain variables from the same country which may forecast the occurrence of integrated reporting models in favor of more traditional reporting models. For this inflexibility, traditional reporting models are those with isolated annual, environmental, social reports and other. The study sample consisted of 309 companies and depends on a number of institutional theories to inspect characteristics of countries where IR is more dominant. Countries with a high investor protection with financial systems characterized by disperse ownership and high degrees of market coordination tend to have integrated reporting. The findings showed that firms are more likely to be based in countries where there is high level of expenditure on tertiary education and higher trade union concentration. In addition, a consciousness of corporate responsibility is a decent indicator of an integrated reported company. Firms that practice IR are more likely to be based in countries which place weight on quality of life, rational values and self-expression etc.

\section{Study design}

This section entails the analysis of the methodological approaches that were used in the research work to achieve the pre-defined objectives. According to (Neuman and Robson 2014), research methodology can be understood as the way of examining a given problem or particular matter. It has been established that in a research 
methodology, different criteria and techniques are used by the researchers to search or solve the given research problem. The proceeding sections incorporate the illustration of different approaches and strategies that were used to identify the percentage of adoption of IR in the banking sector of Bahrain. In this regard, the proceeding sections describe the research approach, data sources, sampling, and data analysis techniques that were used in the research work.

\subsection{Study method}

In accordance with the study of (Flick 2015), research approach can be referred as the methods or strategies that are used during the evaluation, interpretation, and gathering required data. Primarily, research approach facilitates the researchers in making several different decisions to ensure the successful accomplishment of the research approach. These decisions include the identification and adoption of data collection and analysis methods, methods for data interpretation, and philosophical assumptions. This study uses the quantitative methods in order to investigate the IR disclosures in Bahrain banks and get the desired results. The study uses the checklist tool to collect the data and information disclosed on the financial reports of banks listed on Bahrain Bourse. The study aims to examine the implementation level of the IR by listed banks in Bahrain Bourse. This checklist was developed by other researchers in previous studies (e.g., Setia, et al. 2015).

\subsection{Data sources}

Data sources hold undeniable importance in the successful completion of the research work, as it helps researchers in critically analyzing the research problem and related facts. In other words, it can be affirmed that the data sources provide ample amount of reliable information to the researchers that ultimately help in developing a research base; hence, getting a logical interpretation of the research problem. Data sources are mainly of two types, primary data sources and secondary data sources. (Flick 2015) has defined primary data as the one that is collected, directly from the original source. Some of the predominant techniques of collecting primary data include surveys, face-to-face interviews, etc. On the contrary, secondary data is gathered by accessing already published researches and reports. Secondary data is often collected from textbooks, research articles, internet websites, and journals. In the present study, the researchers has used secondary data sources to gather information relevant to the current trends of IR in the banks of Bahrain.

\subsection{Sampling}

To get the desired results, the whole population of all Bahraini Banks was considered and the study limits a sample to consists of all banks that are listed on the Bahrain bourse. However, the data were collected for 12 banks from the period 2014 and 2015. One of the major objectives of selecting this time span was to draw more reliable, updated, and coherent results about the trends of IR in the banking sector of Bahrain. The other sectors other than banks sector are excluded from the study sample as 
industrial and services companies, since their financial reporting are different, and the study is focused on the Banking sector. Namely, AUB BANK, ALSALAM BANK, BISB, BBK, NBB, ABC, BAHRAIN MIDDLE EAST BANK, INVESTCORP BANK, ITHMAR BANK, UNITED GULF BANK, AL BARAKA BANKING GROUP, AND KHALEEJI COMMERCIAL BANK. Nevertheless, two banks has been excluded (BMI has been merged with al-Salam bank and Taib bank has been suspended for the Bahraini bourse through the study period).

\subsection{Data analysis}

In the present study, the researchers have adopted "Content Analysis" technique to analyze the volume and trends of IR implementation in the banking sector of Bahrain. It has been established that content analysis entails information's classification that is disclosed in a source document. One of the most common and widely used types of content analysis is the one in which the absence or presence of a particular item is recognized in a collected information.

For the sake of performing content analysis, the researchers developed a coding scheme around the concept of IR in the banking sector of Bahrain. The coding scheme had included thirty-eight (38) disclosure items that were categorized into four (4) types. These include intellectual capital, social and relational capital, intellectual capital, and human capital. Amid these disclosure items, nine (9) disclosure items were included in intellectual capital, seventeen (17) in the social and relational capital, three (3) in natural capital, and eight (8) in human capital. In this regard, when these items were disclosed within the integrated/annual reports, then there were marked with a score of " 1 "; otherwise marked with a score of " 0 ".

\section{Study results:}

In this section, we present and interpret the findings that have been collected by accessing the reports of twelve (12) different Bahraini banks. The gathered data was examined by using 'content analysis' method - checklist. The data was specifically evaluated by presenting the extent disclosures of capitals (Human capital, Social and relational capitals, Natural capital, Intellectual capital) company-wise and item-wise; and the statistical analysis of change in the extent of disclosure.

\subsection{Extent disclosures of capitals (company-wise)}

The below-mentioned Table 1 represents the total number of disclosure items in the selected disclosure category that are primarily disclosed by the selected banks in the period of 2014-2015. In addition to this, the table also shows the change of percentage in the number of items, which were disclosed by the sample banks, for disclosure categories. The annual report of the sample banks, for the year 2014, shows that the banks on average disclosed (6.5 out of 8 ) human capital items (81.25\%), (9.9 out of 17) social and relational capital items (58\%), (2 out of 3) natural capital items (67\%), and (5.8 out of 9) intellectual capital items (64.8\%). In addition, it has been recognized that the average number of items that had been disclosed by the selected sample of the banks 
in each individual category has been raised from the period of 2014 to 2015; hence, resulted in decreasing human capital items to $(80 \%)$ or (6.4 out of 8$)$.

Moreover, it has also resulted in leading the social and relational capital items from $(58.3 \%) 9.9$ to $(59.8 \%) 10.2$ (out of 17 ); natural capital items were $(67 \%)$ or (2 out of 3 ) for both years, as well as (72.2\%), (6.5 out of 9) intellectual capital items. Nevertheless, it is significant to bring it to the notice that there are three disclosure items in the category of natural capital; thereby, it can be contended that the identified increment holds minimal economic importance. Banks usually do not deal with the natural capital.

In addition to this when the items disclosed in all categories were analyzed in the form of percentage, it was revealed that the category of human capital had scored maximum percentage. The percentage was higher in both of the years, i.e., 2014 and 2015 , as compared to all other categories. In the year 2014, the average percentage was 81.3 per cent and in the year 2015 , it was 80.2 per cent. On the other hand, the findings have also shown least disclosed percentages for social and relational capital in both the years, i.e., 2014 and 2015.

The analysis also shows the average implementation level of IR $65.54 \%$ and $67.79 \%$ for the years 2014 and 2015 respectively. This implementation level of the banks in Bahrain is considered relatively average (medium). In addition, it has been represented in the below-mentioned (Table 1) that the majority of the samples organized have increased the number of disclosed items in 2015, as compared to the year 2014. It has been established that the total number of disclosed items represents a minor reduction in four banks (KHALEEJI COMMERCIAL BANK, ITHMAR BANK, UNITED GULF BANK, BAHRAIN MIDDLE EAST BANK). However, eight banks show an increase of disclosed item (AL BARAKA BANKING GROUP, ALSALAM BANK, BISB, BBK, NBB, ABC, INVESTCORP BANK, and AUB). Apart from this, it is also observed that the Banks that did not bring any change for disclosure items natural capital.

The ranking of the selected banks has also been designed and presented in this section. It is significant to bring it to the notice that the ranking has been carried out on the basis of the number disclosed items of the sample banks. 
Table 1: Extent Disclosure of Capitals (Company-Wise)

\begin{tabular}{|c|c|c|c|c|c|c|c|c|c|c|c|c|c|c|c|c|}
\hline \multirow{3}{*}{ Bank } & \multicolumn{3}{|c|}{ Human capital } & \multicolumn{3}{|c|}{$\begin{array}{c}\text { Social and relational } \\
\text { capital }\end{array}$} & \multicolumn{3}{|c|}{ Natural capital } & \multicolumn{3}{|c|}{ Intellectual capital } & \multirow{2}{*}{\multicolumn{4}{|c|}{ Total $\left(\begin{array}{ll}N & 37\end{array}\right)$}} \\
\hline & \multicolumn{3}{|c|}{$\left(\begin{array}{ll}N & 8\end{array}\right)$} & \multicolumn{3}{|c|}{$\left(\begin{array}{ll}N & 17\end{array}\right)$} & \multicolumn{3}{|c|}{$\left(\begin{array}{ll}N & 3\end{array}\right)$} & \multicolumn{3}{|c|}{$\left(\begin{array}{ll}N & 9\end{array}\right)$} & & & & \\
\hline & 2014 & 2015 & $\%$ & 2014 & 2015 & $\%$ & 2014 & 2015 & $\%$ & 2014 & 2015 & $\%$ & 2014 & $\%$ & 2015 & $\%$ \\
\hline AUB & 7 & 7 & $0 \%$ & 9 & 9 & $0 \%$ & 2 & 2 & $0 \%$ & 6 & 7 & $17 \%$ & 24 & $64.86 \%$ & 25 & $67.57 \%$ \\
\hline ALSALAM BANK & 5 & 7 & $40 \%$ & 13 & 11 & $-15 \%$ & 2 & 2 & $0 \%$ & 5 & 7 & $40 \%$ & 25 & $67.57 \%$ & 27 & $72.97 \%$ \\
\hline BISB & 6 & 6 & $0 \%$ & 9 & 11 & $22 \%$ & 2 & 2 & $0 \%$ & 6 & 5 & $-17 \%$ & 23 & $62.16 \%$ & 24 & $64.86 \%$ \\
\hline BBK & 7 & 7 & $0 \%$ & 11 & 13 & $18 \%$ & 2 & 2 & $0 \%$ & 6 & 6 & $0 \%$ & 26 & $70.27 \%$ & 28 & $75.68 \%$ \\
\hline NBB & 7 & 7 & $0 \%$ & 9 & 10 & $11 \%$ & 2 & 2 & $0 \%$ & 6 & 6 & $0 \%$ & 24 & $64.86 \%$ & 25 & $67.57 \%$ \\
\hline ABC & 6 & 6 & $0 \%$ & 11 & 11 & $0 \%$ & 2 & 2 & $0 \%$ & 5 & 7 & $40 \%$ & 24 & $64.86 \%$ & 26 & $70.27 \%$ \\
\hline BAHRAIN MIDDLE EAST BANK & 7 & 5 & $-29 \%$ & 10 & 10 & $0 \%$ & 2 & 2 & $0 \%$ & 5 & 6 & $20 \%$ & 24 & $64.86 \%$ & 23 & $62.16 \%$ \\
\hline INVESTCORP BANK & 7 & 7 & $0 \%$ & 8 & 10 & $25 \%$ & 2 & 2 & $0 \%$ & 6 & 7 & $17 \%$ & 23 & $62.16 \%$ & 26 & $70.27 \%$ \\
\hline ITHMAR BANK & 7 & 6 & $-14 \%$ & 9 & 9 & $0 \%$ & 2 & 2 & $0 \%$ & 7 & 6 & $-14 \%$ & 25 & $67.57 \%$ & 23 & $62.16 \%$ \\
\hline UNITED GULF BANK & 7 & 6 & $-14 \%$ & 10 & 9 & $-10 \%$ & 2 & 2 & $0 \%$ & 6 & 7 & $17 \%$ & 25 & $67.57 \%$ & 24 & $64.86 \%$ \\
\hline AL BARAKA BANKING GROUP & 5 & 7 & $40 \%$ & 11 & 10 & $-9 \%$ & 2 & 2 & $0 \%$ & 5 & 7 & $40 \%$ & 23 & $62.16 \%$ & 26 & $70.27 \%$ \\
\hline KHALEEJI COMMERCIAL BANK & 7 & 6 & $-14 \%$ & 9 & 9 & $0 \%$ & 2 & 2 & $0 \%$ & 7 & 7 & $0 \%$ & 25 & $67.57 \%$ & 24 & $64.86 \%$ \\
\hline Average & 6.5 & 6.4 & & 9.9 & 10.2 & & 2.0 & 2.0 & & 5.8 & 6.5 & & & & & \\
\hline Average $\%$ & $81.3 \%$ & $80.2 \%$ & & $58.3 \%$ & $\mathbf{5 9 . 8} \%$ & & $67 \%$ & $67 \%$ & & $64.8 \%$ & $72.2 \%$ & & & $65.54 \%$ & & $67.79 \%$ \\
\hline
\end{tabular}


It is observed from the collected data that the ranking for the 12 banks has fallen from their former rankings (i.e., ranking for the year 2014). In this regard, some of the sample (banks) like INVESTCORP BANK has dramatically gone down in 2015, as compared to 2014. It is a noteworthy aspect that the downfall of the banks, in terms of their rankings, is not due the inappropriate disclosure by these organizations; however, the main reason is the better and more improved disclosures by other banks.

On the contrary, commendable efforts have been done by Khaleeji Commerical Bank, United Gulf Bank, and Bahrain Middle East Bank. In orderly presenting more cohesive illustration of the findings, below provided Table 2 shows the collected evidences. It is significant to note that the ranking has been performed on the basis of the score of the total disclosure. Based on this, in 2014 and 2015 the BBK bank has the highest rank in the implementation of IR in Bahrain, followed by ALSALAM BANK. And the lowest implementation level was by BISB, INVESTCORP BANK, AL BARAKA BANKING GROUP, the BAHRAIN MIDDLE EAST BANK and ITHMAR BANK for the year 2014 and 2015.

Table 2: Ranking of the Banks

\begin{tabular}{|c|c|c|c|}
\hline \multirow{2}{*}{ Company name } & \multicolumn{2}{c|}{ Rank } \\
\cline { 3 - 4 } & AUB BANK & $\mathbf{2 0 1 4}$ & $\mathbf{2 0 1 5}$ \\
\hline $\mathbf{1}$ & ALSALAM BANK & 2 & 4 \\
\hline $\mathbf{2}$ & BISB & 4 & 2 \\
\hline $\mathbf{3}$ & BBK & 1 & 1 \\
\hline $\mathbf{5}$ & NBB & 3 & 4 \\
\hline $\mathbf{6}$ & ABC & 3 & 3 \\
\hline $\mathbf{7}$ & BAHRAIN MIDDLE EAST & 3 & 6 \\
\hline $\mathbf{8}$ & BNVESTCORP BANK & 4 & 3 \\
\hline $\mathbf{9}$ & ITHMAR BANK & 2 & 6 \\
\hline $\mathbf{1 0}$ & UNITED GULF BANK & 2 & 5 \\
\hline $\mathbf{1 1}$ & AL BARAKA BANKING & 4 & 3 \\
\hline $\mathbf{1 2}$ & $\begin{array}{c}\text { KHALEEJI COMMERCIAL } \\
\text { BANK }\end{array}$ & 2 & 5 \\
\hline
\end{tabular}

\subsection{Extent disclosure of capitals (item-wise)}

Table 3, mentioned below, depicts the percentages as well as the number of banks that have disclosed each of their individual items in their reports for the year 2014 and 2015. The first panel, i.e., "Panel A" of Table 3 represents the percentages and number of banks that are disclosing their items related to human capital. It has been established from the collected evidences that during the years 2014 and 2015. All of the selected banks have carried out reporting on employee benefits as well as the training and development of the employees. It is also noted that except one of the sampled banks, all organizations had reported and disclosed the employee competence and capabilities, employee experience, employee loyalty and motivation, employee diversity, employee morale, human resource management, employee benefits, human resource development 
at their workplace. However, it is also recognized that this trend had slightly declined in the year 2015.

Some of the organizations were showing resistance in disclosing information on the motivation, loyalty, as well as the morale of their employees in 2015. Apart from panel A, the panel B of Table 3 has illustrated that the practices of the banks in disclosing their natural capital items have remained stable during both years 2014 and 2015. In this regard, the information that has been disclosed by the sampled banks includes "use of and impact on land resources" and "use of and impact on atmospheric resources". It is significant to bring into the notice that more banks have shared their information regarding the "use of and impact on atmospheric as well as land resources" in their integrated reports as compared to their reports that are generated on annual basis. One of the prominent aspects in this regard is that none of the sampled banks have provided information related to their "use of and impact on water resources".

Table 3: Extent disclosure of capitals (item-wise)

\begin{tabular}{|c|c|c|c|c|c|}
\hline Disclosure Items & 2014 & $\%$ & 2015 & $\%$ & $\Delta \%$ \\
\hline \multicolumn{6}{|l|}{ Panel A: human capital } \\
\hline Employee competence and capabilities & 12 & $100.0 \%$ & 12 & $100.0 \%$ & $0.0 \%$ \\
\hline Employee experience & 12 & $100.0 \%$ & 11 & $91.7 \%$ & $8.3 \%$ \\
\hline Employee loyalty and motivation & 10 & $83.3 \%$ & 11 & $91.7 \%$ & $-8.3 \%$ \\
\hline Employee diversity & 10 & $83.3 \%$ & 8 & $66.7 \%$ & $16.7 \%$ \\
\hline Employee morale & 0 & $0.0 \%$ & 0 & $0.0 \%$ & $0.0 \%$ \\
\hline Human resource management & 12 & $100.0 \%$ & 12 & $100.0 \%$ & $0.0 \%$ \\
\hline Employee benefits & 10 & $83.3 \%$ & 11 & $91.7 \%$ & $-8.3 \%$ \\
\hline Human resource development & 12 & $100.0 \%$ & 12 & $100.0 \%$ & $0.0 \%$ \\
\hline \multicolumn{6}{|l|}{ Panel B: natural capital } \\
\hline Use of and impact on land resources & 12 & $100.0 \%$ & 12 & $100.0 \%$ & $0.0 \%$ \\
\hline Use of and impact on atmospheric resources & 12 & $100.0 \%$ & 12 & $100.0 \%$ & $0.0 \%$ \\
\hline Use of and impact on water resources & 0 & $0.0 \%$ & 0 & $0.0 \%$ & $0.0 \%$ \\
\hline \multicolumn{6}{|l|}{ Panel C: social and relational capital } \\
\hline Customer health safety and privacy & 11 & $91.7 \%$ & 9 & $75.0 \%$ & $16.7 \%$ \\
\hline Customer satisfaction & 3 & $25.0 \%$ & 4 & $33.3 \%$ & $-8.3 \%$ \\
\hline Relations with competitors behavior & 1 & $8.3 \%$ & 2 & $16.7 \%$ & $-8.3 \%$ \\
\hline Relations with suppliers & 12 & $100.0 \%$ & 12 & $100.0 \%$ & $0.0 \%$ \\
\hline Relations with lenders & 0 & $0.0 \%$ & 1 & $8.3 \%$ & $-8.3 \%$ \\
\hline Relations with shareholders & 11 & $91.7 \%$ & 12 & $100.0 \%$ & $-8.3 \%$ \\
\hline Human rights & 0 & $0.0 \%$ & 0 & $0.0 \%$ & $0.0 \%$ \\
\hline Indigenous rights & 0 & $0.0 \%$ & 0 & $0.0 \%$ & $0.0 \%$ \\
\hline Involvement in social action & 11 & $91.7 \%$ & 11 & $91.7 \%$ & $0.0 \%$ \\
\hline Social investment & 10 & $83.3 \%$ & 10 & $83.3 \%$ & $0.0 \%$ \\
\hline Donations and charitable work & 12 & $100.0 \%$ & 12 & $100.0 \%$ & $0.0 \%$ \\
\hline Involvement in cultural projects & 1 & $8.3 \%$ & 0 & $0.0 \%$ & $8.3 \%$ \\
\hline Relations with legislators, regulators, policy maker & 12 & $100.0 \%$ & 12 & $100.0 \%$ & $0.0 \%$ \\
\hline Relations with business partners & 6 & $50.0 \%$ & 11 & $91.7 \%$ & $-41.7 \%$ \\
\hline Corporate culture & 12 & $100.0 \%$ & 12 & $100.0 \%$ & $0.0 \%$ \\
\hline Claims and lawsuits & 1 & $8.3 \%$ & 1 & $8.3 \%$ & $0.0 \%$ \\
\hline
\end{tabular}




\begin{tabular}{|l|c|c|c|c|c|}
\hline Relations with employees & 4 & $33.3 \%$ & 1 & $8.3 \%$ & $25.0 \%$ \\
\hline Panel D: intellectual capital & 12 & $100.0 \%$ & 12 & $100.0 \%$ & $0.0 \%$ \\
\hline Corporate governance & 0 & $0.0 \%$ & 0 & $0.0 \%$ & $0.0 \%$ \\
\hline Intellectual property & 11 & $91.7 \%$ & 12 & $100.0 \%$ & $-8.3 \%$ \\
\hline Information technology and information system & 11 & $91.7 \%$ & 11 & $91.7 \%$ & $0.0 \%$ \\
\hline Research and development & 6 & $50.0 \%$ & 11 & $91.7 \%$ & $-41.7 \%$ \\
\hline Processes, policies and procedures & 12 & $100.0 \%$ & 12 & $100.0 \%$ & $0.0 \%$ \\
\hline Organizational structure & 6 & $50.0 \%$ & 8 & $66.7 \%$ & $-16.7 \%$ \\
\hline Brands & 0 & $0.0 \%$ & 0 & $0.0 \%$ & $0.0 \%$ \\
\hline Corporate image & 12 & $100.0 \%$ & 12 & $100.0 \%$ & $0.0 \%$ \\
\hline Market share & &
\end{tabular}

Panel $\mathrm{C}$, incorporated in Table 3 is related to the representation of social and relational capital items disclosure of the banks. It has been recognized from the analysis of the given evidences that the majority of the banks had disclosed their social and relational capital items in 2015 than that of 2014. However, there are certain items that they have not disclosed yet. Some of the prominent items include relations with lenders, human rights, indigenous rights, and claims and lawsuits, as well as involvement in cultural projects. It has been established that the decline in the disclosure of "claims and lawsuits" can be related to the increased need for the banks to comply with the regulations and laws.

The profound and in-depth analysis of the disclosed items has revealed that the banks have become more concerned about their reputation as well as the corporate image. The banks usually try to avoid such issues that could affect or ruin their image in the banks world. Some of the prominent social and relational capital items that have been disclosed by the majority of the banks in 2014 are: customer health safety and privacy, behavior, relations with suppliers, relations with shareholders, involvement in social action, donations and charitable work, social investment, relations with legislators, regulators and policy makers, and banks culture. On the other hand, the items that have been disclosed in the year 2015 include behavior, relations with suppliers, relations with shareholders, involvement in social action, donations, and charitable work, relations with legislators, regulators, and policy makers, relations with business partners, and corporate culture. However, the trend of low reporting of claims and lawsuits remained same in both the years 2014 and 2015.

The panel D of the Table illustrates the reporting of the intellectual capital items of the banks for the year 2014 and 2015. The prominent intellectual capital items that have been reported by the majority of the sampled banks in 2014 include corporate governance, information technology and information system, research and development, organizational structure, and market share. Panel D shows the highest increase for disclosure between 2014 and 2015 from 64\% to $72.2 \%$ which demonstrate that banks are improving the disclosure of those items. The discussed findings are numerically represented in the below mentioned Table 3. Panel A, B, C, and D for 2014 and 2015 are also represented in below mentioned Table 4 and 5 with their sub table for each panel. 


\subsection{Banks rank as per the capitals}

In 2014 AUB (87.5\%) and BBK (87.5\%) topped the human capital where as natural capital remain constant as most of the banks don't use natural capital in their operations for the social relational capital. The BBK became a head of the list again with a disclosure percentage rate of

(79.47\%) followed NBB directly (64.71\%). ITHMAR bank and KHALEEJI

25 commercial bank scores the top rank in intellectual capital with a percentage of disclosure of $(77.78 \%)$ for both banks.

While in 2015 the score remain constant for AUB in the top of the rank with a disclosure percentage of $(87.5 \%)$ in human capital. There is no change in the natural capital in 2016. BBK disclosed the most in social and relational capital followed by AL SALAAM bank with a percentage of $(76.47 \%)$ and $(64.71 \%)$ which is considered a relatively a large gap in disclosure. AUB reached the top of intellectual capital disclosure with the percentage of $(77.78 \%)$. These results are shown in the tables below. 
Table 4: Disclosed items for the year 2014

Table 4 (a): Human Capital

\begin{tabular}{|c|c|c|}
\hline \multicolumn{3}{|c|}{ Panel A: human capital } \\
\hline AHLI UNITED BANK & 7.00 & $87.50 \%$ \\
\hline BANK OF BAHRAIN AND KUWAIT & 7.00 & $87.50 \%$ \\
\hline NATIONAL BANK OF BBHARAIN & 7.00 & $87.50 \%$ \\
\hline BAHRAIN MIDDLE EAST BANK & 7.00 & $87.50 \%$ \\
\hline INVESTCORP BANK & 7.00 & $87.50 \%$ \\
\hline ITHMAR BANK & 7.00 & $87.50 \%$ \\
\hline UNITED GULF BANK & 7.00 & $87.50 \%$ \\
\hline KHALEEJI COMMECIAL BANK & 7.00 & $87.50 \%$ \\
\hline BAHRAIN ISLAMIC BANK & 6.00 & $75.00 \%$ \\
\hline ARAB BANKING CORPORATION & 6.00 & $75.00 \%$ \\
\hline ALSALAM BANK & 5.00 & $62.50 \%$ \\
\hline AL BARAKA BANKING GROUP & 5.00 & $62.50 \%$ \\
\hline
\end{tabular}

Table 4 (b): Natural Capital

\begin{tabular}{|c|c|c|}
\hline \multicolumn{3}{|c|}{ Panel B: natural capital } \\
\hline AHLI UNITED BANK & 2.00 & $66.67 \%$ \\
\hline ALSALAM BANK & 2.00 & $66.67 \%$ \\
\hline BAHRAIN ISLAMIC BANK & 2.00 & $66.67 \%$ \\
\hline BANK OF BAHRAIN AND KUWAIT & 2.00 & $66.67 \%$ \\
\hline NATIONAL BANK OF BBHARAIN & 2.00 & $66.67 \%$ \\
\hline ARAB BANKING CORPORATION & 2.00 & $66.67 \%$ \\
\hline BAHRAIN MIDDLE EAST BANK & 2.00 & $66.67 \%$ \\
\hline INVESTCORP BANK & 2.00 & $66.67 \%$ \\
\hline ITHMAR BANK & 2.00 & $66.67 \%$ \\
\hline UNITED GULF BANK & 2.00 & $66.67 \%$ \\
\hline AL BARAKA BANKING GROUP & 2.00 & $66.67 \%$ \\
\hline KHALEEJI COMMECIAL BANK & 2.00 & $66.67 \%$ \\
\hline
\end{tabular}


Table 4 (c): Social and Relational Capital

\begin{tabular}{|c|c|c|}
\hline \multicolumn{3}{|l|}{ Panel C: social and relational capital } \\
\hline ALSALAM BANK & 13.00 & $76.47 \%$ \\
\hline BANK OF BAHRAIN AND KUWAIT & 11.00 & $64.71 \%$ \\
\hline ARAB BANKING CORPORATION & 11.00 & $64.71 \%$ \\
\hline AL BARAKA BANKING GROUP & 11.00 & $64.71 \%$ \\
\hline BAHRAIN MIDDLE EAST BANK & 10.00 & $58.82 \%$ \\
\hline UNITED GULF BANK & 10.00 & $58.82 \%$ \\
\hline AHLI UNITED BANK & 9.00 & $52.94 \%$ \\
\hline BAHRAIN ISLAMIC BANK & 9.00 & $52.94 \%$ \\
\hline NATIONAL BANK OF BBHARAIN & 9.00 & $52.94 \%$ \\
\hline ITHMAR BANK & 9.00 & $52.94 \%$ \\
\hline KHALEEJI COMMECIAL BANK & 9.00 & $52.94 \%$ \\
\hline INVESTCORP BANK & 8.00 & $47.06 \%$ \\
\hline
\end{tabular}

Table 4 (d): Intellectual Capital

\begin{tabular}{|c|c|c|}
\hline \multicolumn{2}{|l|}{ Panel D: intellectual capital } \\
\hline ITHMAR BANK & 7 & $77.78 \%$ \\
\hline KHALEEJI COMMECIAL BANK & 7 & $77.78 \%$ \\
\hline AHLI UNITED BANK & 6 & $66.67 \%$ \\
\hline BAHRAIN ISLAMIC BANK & 6 & $66.67 \%$ \\
\hline BANK OF BAHRAIN AND KUWAIT & 6 & $66.67 \%$ \\
\hline NATIONAL BANK OF BBHARAIN & 6 & $66.67 \%$ \\
\hline INVESTCORP BANK & 6 & $66.67 \%$ \\
\hline UNITED GULF BANK & 6 & $66.67 \%$ \\
\hline ALSALAM BANK & 5 & $55.56 \%$ \\
\hline ARAB BANKING CORPORATION & 5 & $55.56 \%$ \\
\hline BAHRAIN MIDDLE EAST BANK & 5 & $55.56 \%$ \\
\hline AL BARAKA BANKING GROUP & 5 & $55.56 \%$ \\
\hline
\end{tabular}


Table 5: Disclosed items for the year 2015

Table 5 (a): Human Capital

\begin{tabular}{|c|c|c|}
\hline \multicolumn{3}{|c|}{ Panel A: human capital } \\
\hline AHLI UNITED BANK & 7.00 & $87.50 \%$ \\
\hline ALSALAM BANK & 7.00 & $87.50 \%$ \\
\hline BANK OF BAHRAIN AND KUWAIT & 7.00 & $87.50 \%$ \\
\hline NATIONAL BANK OF BBHARAIN & 7.00 & $87.50 \%$ \\
\hline INVESTCORP BANK & 7.00 & $87.50 \%$ \\
\hline AL BARAKA BANKING GROUP & 7.00 & $87.50 \%$ \\
\hline BAHRAIN ISLAMIC BANK & 6.00 & $75.00 \%$ \\
\hline ARAB BANKING CORPORATION & 6.00 & $75.00 \%$ \\
\hline ITHMAR BANK & 6.00 & $75.00 \%$ \\
\hline UNITED GULF BANK & 6.00 & $75.00 \%$ \\
\hline KHALEEJI COMMECIAL BANK & 6.00 & $75.00 \%$ \\
\hline BAHRAIN MIDDLE EAST BANK & 5.00 & $62.50 \%$ \\
\hline
\end{tabular}

Table 5 (b): Natural Capital

\section{Panel B: natural capital}

\begin{tabular}{|c|c|c|}
\hline AHLI UNITED BANK & 2.00 & $66.67 \%$ \\
\hline ALSALAM BANK & 2.00 & $66.67 \%$ \\
\hline BAHRAIN ISLAMIC BANK & 2.00 & $66.67 \%$ \\
\hline BANK OF BAHRAIN AND KUWAIT & 2.00 & $66.67 \%$ \\
\hline NATIONAL BANK OF BBHARAIN & 2.00 & $66.67 \%$ \\
\hline ARAB BANKING CORPORATION & 2.00 & $66.67 \%$ \\
\hline BAHRAIN MIDDLE EAST BANK & 2.00 & $66.67 \%$ \\
\hline INVESTCORP BANK & 2.00 & $66.67 \%$ \\
\hline ITHMAR BANK & 2.00 & $66.67 \%$ \\
\hline UNITED GULF BANK & 2.00 & $66.67 \%$ \\
\hline AL BARAKA BANKING GROUP & 2.00 & $66.67 \%$ \\
\hline KHALEEJI COMMECIAL BANK & 2.00 & $66.67 \%$ \\
\hline
\end{tabular}


Table 5 (c): Social and Relational Capital

\begin{tabular}{|c|c|c|}
\hline \multicolumn{3}{|l|}{ Panel C: social and relational capital } \\
\hline BANK OF BAHRAIN AND KUWAIT & 13.00 & $76.47 \%$ \\
\hline ALSALAM BANK & 11.00 & $64.71 \%$ \\
\hline BAHRAIN ISLAMIC BANK & 11.00 & $64.71 \%$ \\
\hline ARAB BANKING CORPORATION & 11.00 & $64.71 \%$ \\
\hline NATIONAL BANK OF BBHARAIN & 10.00 & $58.82 \%$ \\
\hline BAHRAIN MIDDLE EAST BANK & 10.00 & $58.82 \%$ \\
\hline INVESTCORP BANK & 10.00 & $58.82 \%$ \\
\hline AL BARAKA BANKING GROUP & 10.00 & $58.82 \%$ \\
\hline AHLI UNITED BANK & 9.00 & $52.94 \%$ \\
\hline ITHMAR BANK & 9.00 & $52.94 \%$ \\
\hline UNITED GULF BANK & 9.00 & $52.94 \%$ \\
\hline KHALEEJI COMMECIAL BANK & 9.00 & $52.94 \%$ \\
\hline
\end{tabular}

Table 5 (d): Intellectual Capital

\begin{tabular}{|c|c|c|}
\hline \multicolumn{3}{|c|}{ Panel D: intellectual capital } \\
\hline AHLI UNITED BANK & 7.00 & $77.78 \%$ \\
\hline ALSALAM BANK & 7.00 & $77.78 \%$ \\
\hline ARAB BANKING CORPORATION & 7.00 & $77.78 \%$ \\
\hline INVESTCORP BANK & 7.00 & $77.78 \%$ \\
\hline UNITED GULF BANK & 7.00 & $77.78 \%$ \\
\hline AL BARAKA BANKING GROUP & 7.00 & $77.78 \%$ \\
\hline KHALEEJI COMMECIAL BANK & 7.00 & $77.78 \%$ \\
\hline BANK OF BAHRAIN AND KUWAIT & 6.00 & $66.67 \%$ \\
\hline NATIONAL BANK OF BBHARAIN & 6.00 & $66.67 \%$ \\
\hline BAHRAIN MIDDLE EAST BANK & 6.00 & $66.67 \%$ \\
\hline ITHMAR BANK & 6.00 & $66.67 \%$ \\
\hline BAHRAIN ISLAMIC BANK & 5.00 & $55.56 \%$ \\
\hline
\end{tabular}




\subsection{Statistical Analysis of Change in the Extent of Disclosure}

Referring to the Table 6, the researchers had conducted the descriptive statistics of different capitals, while presenting the results of paired sample t-sample. One of the major objectives of performing t-tests was to examine the difference between the practices of banks in disclosing items during the years 2014 and 2015. On the basis of collected findings, the average number of disclosed items related to social and relational capital for 2014 was 9.92 (SD 1.37) as compared to 10.17 (SD 1.19) in 2015. The analysis of the results of paired sampled t-test has shown that the average difference amid these items is not statistically significant ( $\mathrm{t}-0.672$ and $\mathrm{p} 0.51)$. In terms of the human capital, the average number of disclosed items in 2014 were 6.50 (SD 0.79) and 6.42 (SD 0.668) in 2015. The difference between these items is also not statistically significant (t 0.247 and p 0.80). However, in the case of intellectual capital items the average disclosure for 2014 is 5.83 (SD 0.717) and for 2015 it is 6.50 (SD 0.67). The difference of these items is statistically significant with the t-value: -0.2152 and p-value: 0.05. This provides evidence that there is no change/progress in the extent of applying (IR) in the two years 2014-2015, except for intellectual capital. Apart from that there is no change in the natural capital due to fact the banks use a very small portion of natural capital in their operations.

Table 6: Statistical Analysis

\begin{tabular}{|c|c|c|c|c|c|c|c|c|c|c|c|}
\hline Panel & Year & Mean & $\mathbf{N}$ & SD & $\begin{array}{c}\text { SE } \\
\text { Mean }\end{array}$ & $\begin{array}{c}\text { Mean } \\
\text { Difference }\end{array}$ & SD & $\begin{array}{c}\text { SE } \\
\text { Mean }\end{array}$ & $t$ & df & $\begin{array}{l}\text { Sig. (2- } \\
\text { tailed) }\end{array}$ \\
\hline \multirow{2}{*}{$\begin{array}{l}\text { Human } \\
\text { capital }\end{array}$} & 2014 & 6.50 & 12 & 0.7977 & 0.2303 & \multirow{2}{*}{0.0833} & \multirow{2}{*}{1.1645} & \multirow{2}{*}{0.34} & \multirow{2}{*}{0.2479} & \multirow{2}{*}{11} & \multirow{2}{*}{0.80} \\
\hline & 2015 & 6.42 & 12 & 0.6686 & 0.1930 & & & & & & \\
\hline \multirow{2}{*}{$\begin{array}{c}\text { Social and } \\
\text { relational } \\
\text { capital }\end{array}$} & 2014 & 9.92 & 12 & 1.3790 & 0.3981 & \multirow{2}{*}{-0.2500} & \multirow{2}{*}{1.2881} & \multirow{2}{*}{0.37} & \multirow{2}{*}{-0.672} & \multirow{2}{*}{11} & \multirow{2}{*}{0.51} \\
\hline & 2015 & 10.17 & 12 & 1.1934 & 0.3445 & & & & & & \\
\hline \multirow{2}{*}{$\begin{array}{l}\text { Natural } \\
\text { capital }\end{array}$} & 2014 & $2.00^{\mathrm{a}}$ & 12 & 0.0000 & 0.0000 & \multirow{2}{*}{--} & \multirow{2}{*}{---} & \multirow{2}{*}{---} & \multirow{2}{*}{---} & \multirow{2}{*}{---} & \multirow{2}{*}{--- } \\
\hline & 2015 & $2.00^{\mathrm{a}}$ & 12 & 0.0000 & 0.0000 & & & & & & \\
\hline \multirow{2}{*}{$\begin{array}{c}\text { Intellectual } \\
\text { capital }\end{array}$} & 2014 & 5.83 & 12 & 0.7177 & 0.2072 & \multirow{2}{*}{-0.6667} & \multirow{2}{*}{1.0731} & \multirow{2}{*}{0.31} & \multirow{2}{*}{-2.152} & \multirow{2}{*}{11} & \multirow{2}{*}{0.05} \\
\hline & 2015 & 6.50 & 12 & 0.6742 & 0.1946 & & & & & & \\
\hline
\end{tabular}

a. The t cannot be computed because the standard error of the difference is 0 .

\section{Conclusion}

The study has profoundly analyzed and discussed the extent of disclosure of the values or core components that drive the organizations. In this regard, the researchers has primarily taken four (4) capital items into the consideration. These include intellectual capital items, natural capital items, social and relational capital items, as well as human capital items. The current research work was solely based on the banking sector of Bahrain and the researchers had collected the required evidence for the period of 2014 and 2015. 
The study can be considered as one of the greatest initiatives towards establishing more cohesive understanding about the importance and relevance of IR practices in the banking sector. It is anticipated that the findings of the research will commendably contribute in the currently available literature. It is due to the fact that the results, shown in the above section, have provided a substantial knowledge about the extent of the disclosure of the items in the top rated banks of Bahrain; hence, encouraging other banks, operating in the same sector, to adopt adequate IR practices.

It has been established from the analysis of the collected findings and results that banks extensively disclose the information that is associated with the intellectual capital items. The statistically significant findings have shown that the banks easily disclose the activities of all items that lie under intellectual capital. Some of the prominent items related to intellectual capital, that the banks disclose are corporate governance, information technology and information systems, research and development, processes, policies, and procedures, organizational structure, and market share.

The IR of all these items is found to be highly effective, in terms of enhancing the repute and standing of the company (banks) in the target market. When the ranking of the sample bank was performed, based on their IR initiatives, it was revealed that BBK bank is at the top of the list, both during 2014 and 2015. Though some of the banks like BISB, INVESTCORP bank, and Al Baraka Banking Group had performed well in 2014, but they did not maintain their practices in 2015 .

In general, the results show that in average adaption level of IR $65.54 \%$ and $67.79 \%$ for the years 2014 and 2015 respectively. This implementation level of the banks in Bahrain is considered relatively average (medium). In addition, BBK has the highest rank for disclosure while ITHMAR and Bahrain middle east was the least. However, a large change can be noticed in both the banks, an increase has been noted in both years.

Therefore, it is anticipated that the present research work will inevitably help banks in improving their integrated reporting practices so as to increase their ranking among other Bahraini banks. The in-depth analysis of the research results has also concluded that the banks tend to present their non-financial information, like human capital, especially when their disclosures are assessed under certain regulations/laws. It is due to the fact that any flaw, identified during the scrutiny could lead the company towards irreparable losses, in terms of integrity and repute. However, the banks hold the liability to ensure highest level of transparency and honesty, during integrated reporting.

As far as the limitations of the study been concerned, one of the biggest limitations that are associated with the study is the small sample size. The researchers could select more banks, apart from the listed ones, to enhance the credibility of the results. Apart from this, another limitation of the current study is the selection of the timespan for the selection of financial reports. In particular, the researchers had assessed only those financial reports of the banks, which were published between 2014 and 2015; the researchers could broaden this time period and could examine the integrated reporting trends for the past five to ten years to present the clear difference in the practices of banks, specifically in integrated reporting. Therefore, it is recommended to the researchers to consider these aspects so as to carry out more in-depth and profound research work. 
It is recommended to the banking sector of Bahrain to implement a special emphasis on disclosing their capital items, during integrated reporting. Some of the major areas that are needed to be focused in this regard are: employee morale, use of and impact on water resources, relations with competitors, relations with lenders, human rights, and indigenous rights, involvement in cultural projects, claims and lawsuits, relations with employees, intellectual property, and corporate image. Fair and transparent disclosure of these capital items would help the Bahraini banks to establish strong repute, both in the local and international markets. In addition to this, such practices would also enable the Bahraini banks to develop strong and long-term relationships with their stakeholders.

For upcoming research, the study of IR in banking sector can open the opportunities to study other financial institutions like insurance companies or even the industrial sector. Also adding more than two years would give a better comparison effect with a wider view of the measurement.

\section{References:}

Abeysekera, I. (2013). A template for integrated reporting. Journal of Intellectual Capital, 14(2), 227-245. https://doi.org/10.1108/14691931311323869

Alareeni, B. (2017). The association between audit firm characteristics and audit quality: A meta-analysis. (SSRN Working Papers No. 2952836). Social Sciences Research Network. https://doi.org/10.2139/ssrn.2952836

Alareeni, B., \& Aljuaidi, O. (2014). The modified Jones and Yoon models in detecting earnings management in Palestine Exchange (PEX). International Journal of Innovation and Applied Studies, 9(4), 2028-9324.

Alareeni, B., \& Branson, J. (2011). The relative performance of auditors' going-concern opinions and statistical failure prediction models in Jordan. Accountancy \& Bedrijfskunde, 8, 23-35.

Alareeni, B., \& Branson, J. (2013). Predicting listed companies' failure in Jordan using Altman models: A case study. International Journal of Business and Management, 8(1), 113-126. https://doi.org/10.5539/ijbm.v8n1p113

Alareeni, B., \& Deghish, H. (2016). Applicability of the balanced scorecard to assess performance of Al-Aqsa media network institution in Gaza Strip. IUG Journal of Economics and Business Studies, 24(3), 21-46. https://doi.org/10.12816/00355

Al-Sartawi, A. (2013). The impact of corporate governance on GCC listed banks performance: Comparative study between the Islamic and non-Islamic banks. Attaawun Journal, 79, 66-90.

Al-Sartawi, A. (2017). The level of disclosing intellectual capital in the gulf cooperation council countries. International Research Journal of Finance and Economics, 159, 90-99.

Bryman, A. (2015). Social research methods. Oxford: Oxford University Press.

De Villiers, C., Rinaldi, L., \& Unerman, J. (2014). Integrated reporting: Insights, gaps and an agenda for future research. Accounting, Auditing \& Accountability Journal, 27(7), 1042-1067. https://doi.org/10.1108/AAAJ-06-2014-1736 
Deegan, C. (2002). Introduction: The legitimising effect of social and environmental disclosures-A theoretical foundation. Accounting, Auditing \& Accountability Journal, 15(3), 282-311. https://doi.org/10.1108/09513570210435852

Dragu, I. M., \& Tiron-Tudor, A. (2013). The integrated reporting initiative from an institutional perspective: Emergent factors. Procedia-Social and Behavioral Sciences, 92, 275-279. https://doi.org/10.1016/j.sbspro.2013.08.672

Flick, U. (2015). Introducing research methodology: A beginner's guide to doing a research project. London: Sage Publication Ltd.

Frías-Aceituno, J. V., Rodríguez-Ariza, L., \& García-Sánchez, I. M. (2013). Is integrated reporting determined by a country's legal system? An exploratory study. Journal of Cleaner Production, 44, 45-55. https://doi.org/10.1016/j.jclepro.2012.12.006

García-Sánchez, I. M., Rodríguez-Ariza, L., \& Frías-Aceituno, J. V. (2013). The cultural system and integrated reporting. International Business Review, 22(5), 828-838. https://doi.org/10.1016/j.ibusrev.2013.01.007

Gray, R., Kouhy, R., \& Lavers, S. (1995). Constructing a research database of social and environmental reporting by UK companies. Accounting, Auditing \& Accountability Journal, 8(2), 78-101. https://doi.org/10.1108/09513579510086812

Halbritter, G., \& Dorfleitner, G. (2015). The wages of social responsibility-Where are they? A critical review of ESG investing. Review of Financial Economics, 26, 25 35. https://doi.org/10.1016/j.rfe.2015.03.004

Hamdan, A., Buallay, A., \& Alareeni, B. (2017). The moderating role of corporate governance on the relationship between intellectual capital efficiency and firm. International Journal of Learning and Intellectual Capital, 14(4), 295-318. https://doi.org/10.1504/IJLIC.2017.087377

International Integrated Reporting Council. (2013). International $\langle I R\rangle$ framework.

Integrated Reporting Council of South Africa (IRCSA). (2011, January). Framework for integrated reporting and the integrated report.

Jensen, J. C., \& Berg, N. (2013). Determinants of traditional sustainability reporting versus integrated reporting: An institutionalist approach. Business Strategy and the Environment, 21(5), 299-316. https://doi.org/10.1002/bse.740

Institute of Directors in Southern Africa. (2002) King report on corporate governance for South Africa- 2002 (King II report).

Makiwane, T. S., \& Padia, N. (2013). Evaluation of corporate integrated reporting in South Africa post King III release South Africa: An exploratory enquiry. Journal of Economic and Financial Sciences, 6(2), 421-438. https://doi.org/10.4102/jef.v6i2.268

Neuman, W.L., \& Robson, K., (2014). Basics of social research: Qualitative and quantitative approaches ( $3^{\text {rd }}$ Ed.). Boston: Pearson.

Rensburg, R., \& Botha, E. (2014). Is integrated reporting the silver bullet of financial communication? A stakeholder perspective from South Africa. Public Relations Review, 40(2), 144-152. https://doi.org/10.1016/j.pubrev.2013.11.016

Ruiz-Lozano, M., \& Tirado-Valencia, P. (2016). Do industrial companies respond to the guiding principles of the Integrated Reporting framework? A preliminary study on 
the first companies joined to the initiative. Revista De Contabilidad, 19(2), 252260. https://doi.org/10.1016/j.rcsar.2016.02.001

Salvioni, D. M., \& Bosetti, L. (2014). Stakeholder engagement and integrated reporting: Evidence from the adoption of the IIRC Framework. Journal of Strategic and International Studies, 9(3), 78-89.

Setia, N., Abhayawansa, S., Joshi, M., \& Huynh, A. V. (2015). Integrated reporting in South Africa: Some initial evidence. Sustainability Accounting, Management and Policy Journal, 6(3), 397-424. https://doi.org/10.1108/SAMPJ-03-2014-0018

Simnett, R., Vanstraelen, A., \& Chua, W. F. (2009). Assurance on sustainability reports: An international comparison. The Accounting Review, 84(3), 937-967. https://doi.org/10.2308/accr.2009.84.3.937

Suchman, M. C. (1995). Managing legitimacy: Strategic and institutional approaches. Academy of Management Review, 20(3), 571-610. https://doi.org/10.5465/amr.1995.9508080331 